\title{
Phytophthora Species Recovered From Irrigation Reservoirs in Mississippi and Alabama Nurseries and Pathogenicity of Three New Species
}

Warren E. Copes, Agricultural Research Service, US Department of Agriculture, Poplarville, Mississippi, 39470; and Xiao Yang and Chuanxue Hong, Department of Plant Pathology, Physiology and Weed Science, Hampton Roads Agricultural Research and Extension Center, Virginia Polytechnic Institute and State University, Virginia Beach, Virginia, 23455

\begin{abstract}
Copes, W. E., Yang, X., and Hong, C. X. 2015. Phytophthora species recovered from irrigation reservoirs in Mississippi and Alabama nurseries and pathogenicity of three new species. Plant Dis. 99:1390-1395.

From a survey for Phytophthora spp. in containment basins at one nursery each in Alabama and Mississippi, eight species and one taxon were recovered, with Phytophthora gonapodyides dominant in cooler months and $P$. hydropathica in warmer months, accounting for 39.6 and $46.6 \%$ overall recovery, respectively. Among the recoveries were $P$. macilentosa, $P$. mississippiae, and $P$. stricta, three new species recently described from a small lake (labeled M4) that serves as a primary water source for irrigation and to feed another irrigation pond (M5) at the Mississippi nursery. Neither of ponds M4 and M5 directly receives runoff from any production area. The three new species were

tested for pathogenicity with Catharanthus roseus, Gardenia jasminoides 'August Beauty,' Hydrangea quercifolia 'Semmes Beauty,' Ilex magland 'Oakland,' Pieris japonica 'Mountain Snow,' and Rhododendron $\times$ 'Brandi Michele Raley.' None of the three species infected any of the test plants or became established in peat or pine bark growing media. Based on the result of pathogenicity trials as well as the field observation that none of the nine Phytophthora taxa recovered from irrigation reservoirs have caused episodic disease in the nurseries, they appear to not present a high risk to ornamental plants at those nurseries.
\end{abstract}

Phytophthora diseases have historically caused serious crop loss in ornamental plant nurseries, and thus have created a deeply seated concern in the industry. In the last decade, the number of named Phytophthora species has doubled and many of the new Phytophthora species are being discovered in open waterways and forest areas (Kroon et al. 2012). As nurseries develop the capacity to pump irrigation water from containment basins that capture runoff from nursery production areas, even more attention and concern are being focused on the dispersal of Phytophthora spp. by irrigation water (Bush et al. 2003; Hong et al. 2008a; Loyd et al. 2014; Olson and Benson 2011; Schwingle and Blanchette 2008; Warfield et al. 2008; Yakabe et al. 2009). The dispersal pattern of Phytophthora spp. in plant production nurseries is complex because sources and spread of inoculum may depend on which Phytophthora spp. are present and could conceivably result from the movement of diseased plant material within and between nurseries, natural vegetation surrounding production areas, wind-blown particles carrying inoculum, over-seasoning inoculum present in asymptomatic nursery stocks, as well as from Phytophthora propagules in irrigation water.

In the last decade, a concerted multistate research effort was undertaken to track the spread of $P$. ramorum on ornamental plants shipped to nurseries throughout the United States (Cobb et al. 2012; Rizzo et al. 2002, 2005). The research generated lists of Phytophthora spp. recovered from symptomatic leaf, stem, crown, and root tissues; and from organic substrate, soil, and waterways in nursery production systems (Bush et al. 2003; Dart and Chastagner 2007; Dart et al. 2007; Ghimire et al. 2009, 2011; Olson and Benson 2011; Olson et al. 2013; Schwingle et al. 2007; Warfield et al. 2008; Yakabe et al. 2009). Interestingly, species diversity varied with location, sampling source, and season. Many Phytophthora spp. recovered from nursery

Corresponding author: Warren E. Copes, E-mail: warren.copes@ars.usda.gov

Accepted for publication 26 February 2015.

http://dx.doi.org/10.1094/PDIS-11-14-1197-RE

This article is in the public domain and not copyrightable. It may be freely reprinted with customary crediting of the source. The American Phytopathological Society, 2015. containment basins are proven pathogens of ornamental plants, but are not all equally virulent or fully elucidated as to their persistence in containment basins (Hong and Moorman, 2005; Hong et al. 2008b; Loyd et al. 2014; Parke et al. 2014; Zappia et al. 2014). In addition, a number of new Phytophthora spp. are being discovered in nursery waterways, with a similar occurrence resulting from increased sampling in riparian and forestry areas (Hong et al. 2008a, 2012; Jung et al. 2011; Yang and Hong, 2013; Yang et al. 2012, 2013, 2014).

A further progression of knowledge will be needed to understand the disease development components of all these Phytophthora spp. in an ecological and epidemiological context (Kroon et al. 2012; Zappia et al. 2014). Parke et al. (2014) found seven Phytophthora spp. that were recovered only from containment basins, and thus were not associated with ornamental plant disease symptoms or the rooting media in the same nursery. Conversely, they found 10 Phytophthora spp. were recovered only from rooting media or diseased plant tissues and not associated with containment basins (Parke et al. 2014). Loyd et al. (2014) found that most Phytophthora spp. recovered from waterways were not pathogenic on Rhododendron or Pieris, while two commonly recovered aquatic species, $P$. hydropathica and $P$. irrigata, caused only foliar disease without infecting roots (Loyd et al. 2014).

Collectively, a large number of Phytophthora spp. are known to be present in nurseries; however, the specific selection is limited within a single nursery and diversity varies by climate, region, and nursery. The same diversity pattern applies to irrigation systems, albeit with a further reduction in the number of Phytophthora spp. recovered. Overall, a limited characterization of disease potential exists resulting from the dispersal of waterborne oomycetes in irrigation water (Zappia et al. 2014). However, the frequency of Phytophthora diseases in ornamental plant nurseries shows that a better understanding of the risks and management is needed. There is little data about their presence at ornamental crop nurseries in the Gulf Coast states. In this study, we surveyed multiple containment basins at two nurseries, one in Alabama (AL) and one in Mississippi (MS). We also evaluated pathogenicity of three newly named Phytophthora spp. on six common woody nursery crops.

\section{Materials and Methods}

Nursery ponds and general water flow. Ponds were sampled at two nurseries. A total of three ponds were sampled from a nursery in 
AL (labeled A1, A2, and A3; Fig. 1). A1 is a 1-acre pond of about $2 \mathrm{~m}$ depth that receives water from a stream that comes from off the property and runoff from multiple container pads on the nursery. Several row crop farms are located in the watershed that drains into the stream. A2 is a 3 -acre pond of about $1.6 \mathrm{~m}$ depth that receives water from pond A1 and runoff from multiple container pads. A3 is a 0.3acre pond of about $6 \mathrm{~m}$ depth located at the highest spot on the property and fed strictly from a well and rainwater. A total of five ponds were sampled from a nursery in MS (labeled M1, M2, M3, M4, and M5; Fig. 2). Ponds M1, M2, and M3 receive runoff directly from multiple container pads. M1 is a 0.4-acre sedimentation pond of about $1 \mathrm{~m}$ depth that receives the largest volume of runoff. It drains directly into M2, a 3-acre pond of about $4 \mathrm{~m}$ depth that overflows into a lagoon (not labeled in this paper), then into M3. M3 is a 2-acre pond of about $1.5 \mathrm{~m}$ depth. M4 is an 8-acre lake of about $3 \mathrm{~m}$ depth. It receives no runoff from the nursery and is fed by a stream and surrounded by wooded habitat. M5 is a 0.7 -acre pond of about $3.5 \mathrm{~m}$ depth that receives water pumped from M4 and occasionally directed from M2, but no direct runoff from the nursery. Both nurseries follow strict sanitation protocols and other best management practices and did not have any major outbreak of Phytophthora diseases on their properties during the study period.

Baiting for Phytophthora species. Ponds in the Alabama nursery were baited with Rhododendron catawbiense 'Boursault' leaves on May 11 to 18, 2011; February 27 to March 6, 2012; and December 11 to 17,2012 . The nursery was closed in late 2012 , so no additional samples were taken. Ponds in the Mississippi nursery were baited with $R$. catawbiense 'Boursault' leaves on May 10 to 17, 2011; February 14 to 21, 2012; November 12 to 19, 2012; and April 23 to 30, 2013. Leaves were deployed as bait at approximately $10 \mathrm{~cm}$ below the surface, midpond depth, and $10 \mathrm{~cm}$ above the bottom of the pond. Three whole leaves were suspended in a mesh bag per depth from a weighed fishing line attached to a float.

Water temperature and $\mathbf{p H}$. Water samples were collected from respective depths with a WaterMark horizontal polycarbonate water sampler (Forestry Suppliers, Inc., Jackson, MS) when leaf baits were deployed and recovered. Water properties $(\mathrm{pH}$, temperature, electrical conductivity, total dissolved salts, salinity, and dissolved oxygen) were measured onsite with a handheld Hach sesION156 multiparameter meter (Hach Co., Loveland, CO) or a Hydrolab DS5x multiparameter water quality sonde (OTT Hydromet, Loveland, CO) after September 19, 2012.

Isolation and isolate maintenance. Leaf baits were deployed in the ponds for 7 days (Bush et al. 2003). Leaves were gently washed in the pond at the time of collection, placed in a zip lock bag, stored in a cooler with an ice pack, and transferred to a laboratory. Leaf baits per depth were cut into approximately fifty $1 \times 1 \mathrm{~cm}^{2}$ sections and 10 excised sections were plated onto each of the $\mathrm{P}_{10} \mathrm{ARP}$ (contains pimarcin, ampicillin, rifampicin, and pentachloronitrobenzene) and $\mathrm{P}_{10} \mathrm{ARPH}\left(\mathrm{P}_{10} \mathrm{ARP}\right.$ ingredients plus hymexazol) selective media (Jeffers and Martin 1986), using standard aseptic techniques. Phytophthora colonies emerging from the edge of bait sections were hyphal-tipped onto $20 \%$ clarified V8 juice agar (cV8A) to obtain pure cultures (Erwin and Ribeiro 1996). Colonies were initially selected by phenotypic traits (mycelium growth habit, density, and color). A minimum of $10 \%$ of each colony type was transferred into pure culture, while from 20 to $100 \%$ were transferred as total colony number lessened. Isolates were shipped to the Hampton Roads Agricultural Research and Extension Center, Virginia Polytechnic Institute and State University, Virginia Beach, VA for identification. Cultures were maintained on cV8A. Representative isolates were placed in long-term storage by transferring blocks of fresh agar cultures into microtubes with sterile distilled water and stored at $15^{\circ} \mathrm{C}$.

Identification of Phytophthora isolates. Phytophthora isolates were first grouped and identified by single-strand-conformation polymorphism (SSCP) DNA fingerprinting by comparing band patterns of reference species (Gallegly and Hong 2008; Kong et al. 2003). Species identities were confirmed by morphological characters (Erwin and Ribeiro 1996; Gallegly and Hong 2008). Three new species recovered from the Mississippi nursery, $P$. macilentosa, $P$. mississippiae, and P. stricta, have been described based on distinct morphological, physiological, and molecular characteristics (Yang et al. 2013, 2014).

Pathogenicity trial. $P$. macilentosa (isolate 58A7), P. mississippiae (isolates 57J2 and 57J3), and P. stricta (isolate 58A1) were inoculated on Catharanthus roseus, Gardenia jasminoides 'August Beauty,' Hydrangea quercifolia 'Semmes Beauty,' Ilex magland 'Oakland,' Pieris japonica 'Mountain Snow,' and Rhododendron $\times$ 'Brandi Michele Raley' at the Thad Cochran Southern Horticultural Laboratory (TCSHL), Poplarville, MS. Plant genera and species were selected based on a general history of susceptibility to Phytophthora spp. and the test was performed twice, each with three replicate plants per isolate and inoculation treatment. Shrubs were purchased in April 2013 from wholesale nurseries and the annual, C. roseus, obtained from a retail outlet. All shrubs, except Rhododendron, were finished plants from propagation facilitates in 0.52-liter containers. Plants were transferred into 1.8-liter containers of peat and pine bark substrate (Fafard 2B; Conrad Fafard, Agawam, MA). The C. roseus plants were moved up to 0.52-liter containers. The Rhododendron $\times$ 'Brandi Michele Raley' was purchased and kept in the 2.7-liter containers throughout the experiment period.

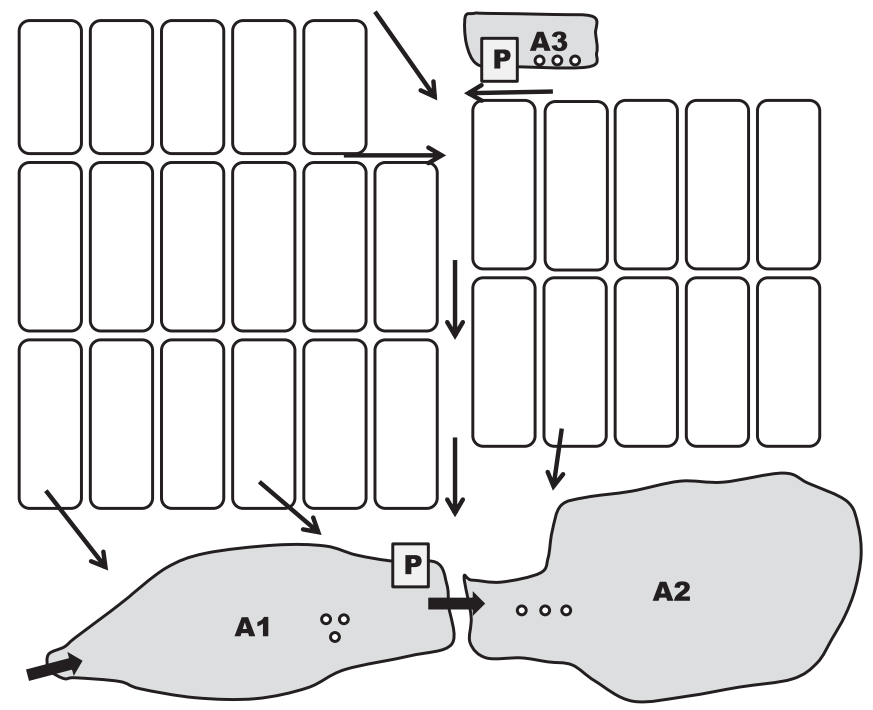

Fig. 1. Illustration of relative pond positions and water flow on a nursery in Alabama. Wide arrows are water flow, narrow arrows are direction of runoff, three grouped open circles are location of leaf bait traps, and square with a ' $P$ ' is a pump station. The image does not encompass the entire nursery.

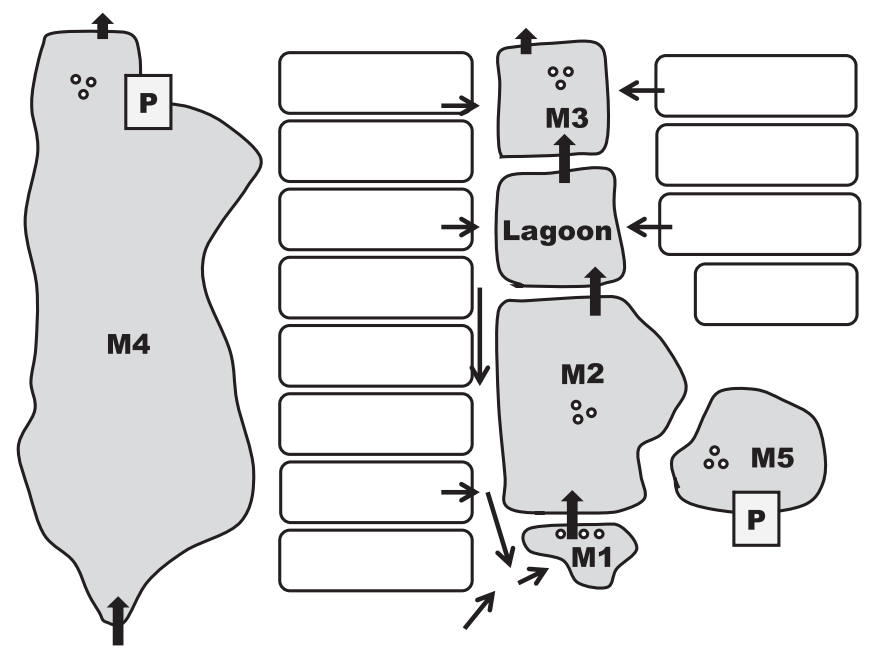

Fig. 2. Illustration of relative pond positions and water flow on a nursery in Mississippi. Wide arrows are water flow, narrow arrows are direction of runoff, three grouped open circles are location of leaf bait traps, and square with a ' $P$ ' is a pump station. The image does not encompass the entire nursery. 
Phytophthora-colonized rice grain used as inoculum was prepared by autoclaving $25 \mathrm{~g}$ of long grain rice in $18 \mathrm{ml}$ distilled water in a 250 -ml Erlenmeyer flask twice within a $24 \mathrm{~h}$ period. Cooled rice grains in each flask were inoculated with 10 pieces $\left(0.5 \mathrm{~cm}^{2}\right)$ of an actively growing culture of the test isolate on cV8A (Stewart and Robertson 2012). Inoculated rice grains were kept at room temperature (about $22^{\circ} \mathrm{C}$ ) for 14 days and shaken by hand once per day to prevent clumping. In trial 1, plants were inoculated on April 22 to 23, 2013, and the final plant ratings and isolations were done on July 24 to 28, 2013. In trial 2, plants were inoculated on September 12 to 13, 2013, and the final plant rating and isolations done on January 6 to 10, 2014.

Inoculations were performed with one isolate at a time to minimize cross-contamination. Scalpels and tweezers were flame-sterilized between samples. Nitrile gloves were worn and changed or washed with denatured alcohol between each plant. Each plant was laid horizontally on a new paper towel. Three inoculation method-sites (nonwounded roots, wounded roots, and wounded collar) were employed. For wounded root inoculation, several root tips were severed at a midarea with a confluent group of roots on one side of a pot, a slight indentation was pressed into the media with a thumb, eight grains of inoculated rice were set with tweezers on the wounded roots, and a small volume of rooting media placed on top of the rice grains and pressed into the depression. The same procedure was used for nonwounded root inoculation, except root tips were not sliced off. For wounded crown inoculation, three shallow cuts were made through the bark into the cambium in a $0.25-\mathrm{cm}^{2}$ square area about $1 \mathrm{~cm}$ above the soil line, tweezers were used to place eight grains of inoculated rice on the wounds, and the rice grains and trunk wrapped with Parafilm (Pechiney Plastic Packaging, Menasha, WI).

Treatments were placed in a strip-split plot design on an outdoor pad under overhead irrigation. Plant species were randomized within blocks and Phytophthora isolate and inoculation type were randomized within plant species. Plants in 1.8-liter containers were set in three plastic trays $(25.4 \times 53.3 \times 5.7 \mathrm{~cm})$ with 0.43 -liter square containers either inverted or filled with gravel separating plant containers within trays. Rhododendrons in 2.7-liter containers were randomized in a wooden frame that held plants upright. Plants were watered daily.
Disease assessment and pathogen isolation. Plant symptoms were assessed at the start, midpoint, and end of the trial on a 0 to 5 categorical scale: 0 , no symptoms; and 5, dieback of main stems (Hong et al. 2012). Final symptom assessment and isolations were processed over 1.5 days per replication. Approximately a $5 \mathrm{~g}$ composite sample of peat based media was collected from the bottom of each container and placed in a zip lock bag. A $1 \mathrm{~g}$ sample of the composite organic media was inserted in a borosilicate glass $16 \times$ $100 \mathrm{~mm}$ culture tube (No. 14-961-29, Fisher Scientific, Inc., Pittsburgh, PA), mixed with $5 \mathrm{ml}$ autoclaved reverse osmosis (RO) water, and capped with aluminum foil. Test tubes were vortexed for $2 \mathrm{~min}$ and a 100- $\mu$ l water sample was drawn and spread over the surface of $\mathrm{P}_{10}$ ARP agar in $100 \mathrm{~mm}$ diameter petri plates. After 2 to 3 days, plates were visually checked for colonies of Phytophthora spp. Suspect isolates were hyphal-tip transferred onto $\mathrm{P}_{10} \mathrm{ARP}$ agar.

Destructive sampling involved removal of aerial plant tissue above the crown inoculation site with a large pruner. Peat or pine bark media was washed from roots using water pressure through a hose and spray nozzle, then the trunk and roots were placed in a plastic bag. Trunk collar symptoms were assessed on a 0 to 5 ordinal scale: 0 , healthy appearance; and 5 , necrosis extending $>20 \mathrm{~mm}$ from wound scars. Percentage of root system necrosis was assessed on a 0 to 5 ordinal scale: $0,0 \%$; and 5, $>20 \%$. Plant trunk and roots were submersed in $10 \%$ bleach solution $(6.25 \%$ sodium hypochlorite, The Clorox Co., Oakland, CA) for 2 min then rinsed in two beakers of $\mathrm{RO}$ water. When plant necrosis was evident, a section of tissue comprising discolored and healthy colored tissue was removed with a flame-sterilized scalpel and plated on $\mathrm{P}_{10} \mathrm{ARP}$ agar. Plates were visually checked at 1 to 2 day intervals over 7 days for the presence of Phytophthora. Phytophthora suspect isolates were hyphal-tip transferred onto $\mathrm{P}_{10} \mathrm{ARP}$. Species identification was derived by morphological and genetic traits as described above.

\section{Results}

Mean pond temperature, averaged over depth and all ponds, followed an expected seasonal pattern (Table 1). Differences in other water quality factors seemed more reflective of individual pond character.

Table 1. Mean pond water environment measurements averaged over two to four depths (near surface and at $1 \mathrm{~meter}$ intervals), three replications ( 1 to $2 \mathrm{~m}$ apart), and 1 to 2 days being at the initial submergence and/or collection of leaf baits from ponds located in an Alabama and Mississippi nursery

\begin{tabular}{|c|c|c|c|c|c|c|}
\hline State & Pond & $\operatorname{Date}(\mathbf{s})^{\mathbf{a}}$ & Temperature $\left({ }^{\circ} \mathrm{C}\right)$ & $\mathbf{p H}\left(-\log \mathbf{H}^{+}\right)$ & Dissolved oxygen (mg/liter) & Specific conductivity $(\mu \mathrm{S} / \mathrm{cm})$ \\
\hline \multirow[t]{12}{*}{$\mathrm{AL}$} & A1 & $5 / 11,18 / 2011$ & 25.4 & 7.4 & 8.4 & 56.5 \\
\hline & & $3 / 5 / 2012$ & 18.1 &.${ }^{\mathrm{b}}$ & . & 59.8 \\
\hline & & $7 / 12 / 2012$ & 28.9 & 6.7 & 6.1 & 66.2 \\
\hline & & $12 / 10,18 / 2012$ & 15.9 & 8.0 & 6.9 & 89.7 \\
\hline & $\mathrm{A} 2$ & $5 / 11,18 / 2011$ & 27.9 & 8.5 & 12.1 & 152.4 \\
\hline & & $3 / 5 / 2012$ & 16.6 & . & . & 88.0 \\
\hline & & $7 / 12 / 2012$ & 29.7 & 8.1 & 6.8 & 94.2 \\
\hline & & $12 / 10,18 / 2012$ & 16.4 & 7.5 & 6.5 & 145.0 \\
\hline & A3 & $5 / 11,18 / 2011$ & 25.1 & 7.0 & 20.7 & 51.4 \\
\hline & & $3 / 5 / 2012$ & 20.3 & & 年 & 44.1 \\
\hline & & $7 / 12 / 2012$ & 27.0 & 6.0 & 3.0 & 54.0 \\
\hline & & $12 / 10,18 / 2012$ & 17.1 & 7.3 & 7.7 & 55.7 \\
\hline \multirow[t]{13}{*}{ MS } & M1 & $5 / 10,17 / 2011$ & 30.1 & 7.0 & 5.8 & 261.5 \\
\hline & & $7 / 11 / 2012$ & 29.0 & 7.4 & 2.8 & 216.5 \\
\hline & M2 & $7 / 11 / 2012$ & 27.5 & 8.8 & . & 181.1 \\
\hline & & $11 / 19,29 / 2012$ & 14.6 & 8.3 & 8.9 & 143.8 \\
\hline & M3 & $5 / 10,17 / 2011$ & 24.3 & 7.0 & 4.3 & 139.6 \\
\hline & & $7 / 11 / 2012$ & 28.6 & 7.1 & 3.2 & 162.2 \\
\hline & & $11 / 19,29 / 2012$ & 14.4 & 7.4 & 7.9 & 168.5 \\
\hline & M4 & $5 / 10,17 / 2011$ & 25.8 & 6.8 & 4.6 & 35.4 \\
\hline & & $7 / 11 / 2012$ & 29.4 & 7.3 & . & 23.4 \\
\hline & & $11 / 19,29 / 2012$ & 13.8 & 5.7 & 8.6 & 20.0 \\
\hline & M5 & $5 / 10,17 / 2011$ & 25.6 & 8.1 & 6.1 & 60.1 \\
\hline & & $7 / 11 / 2012$ & 28.2 & 8.4 & 3.4 & 145.8 \\
\hline & & $11 / 19,29 / 2012$ & 14.7 & 8.1 & 11.0 & 69.5 \\
\hline
\end{tabular}

${ }^{a}$ Date is the (month) / (day leaf baits were placed in pond), (day leaf baits were collected) / (year). On July 11, 2012, water quality measurements were taken only on the day leaf bait samples were collected.

b Sensor malfunctioned so data not available. 
Phytophthora species were recovered on all sampling dates from all ponds, but not at all depths, with the exception that no Phytophthora spp. were recovered from pond A3. Phytophthora gonapodyides and/or $P$. hydropathica were recovered during most seasons from ponds, and usually were recovered at a higher frequency than other Phytophthora species. Alabama nursery ponds yielded $P$. gonapodyides, $P$. hydropathica, and $P$. irrigata (Table 2). $P$. gonapodyides was recovered only in March and December, but at all depths and at a higher frequency than other Phytophthora spp. from ponds A1 and A2. P. hydropathica was recovered at a high frequency from all depths in May, but at a low frequency in March and December. $P$. irrigata was recovered only in December at a low frequency and only at the middle depth.

Mississippi nursery ponds yielded $P$. citrophthora, $P$. gonapodyides, $P$. hydropathica, $P$. macilentosa, $P$. mississippiae, $P$. pini, $P$. stricta, and $P$. taxon PgChlamydo (Table 3). P. gonapodyides was recovered from all five ponds, mostly from all depths, but only during February and November. $P$. gonapodyides was recovered at a higher frequency in ponds M1, M2, and M3, and at lower frequency in ponds M4 and M5. P. hydropathica was recovered at a higher frequency in ponds M1, M2, M3, and M5, mostly from all depths, in three of the four months sampled. Phytophthora taxon PgChlamydo was recovered only in April, only from the middle depth in M2, only from the bottom depth in M3, and from all depths in M5. P. citrophthora was recovered only in April, only at the middle depth in M2, only at the bottom depth in M5, and at a low frequency. P. macilentosa was recovered from all depths in February and April, but only from pond M4. P. mississippiae was recovered at all depths at a low frequency, but only from M4 in February. P. stricta was recovered only at a low frequency at the near-surface depth and only from M4 in February.

The three new species, $P$. macilentosa, $P$. mississippiae, and $P$. stricta, recovered from pond M4, were used to inoculate six ornamental plant genera. The use of eight colonized rice grains per site were considered a high inoculum load and viability was verified by mycelium growth on cV8 media. None of the three species were recovered from plant tissue or from the organic growing media when the trial was terminated 95 and 115 days after inoculations in trials 1 and 2, respectively. Plant and root disease ratings are not shown since the four inoculated isolates did not infect and cause disease. However, $P$. cinnamomi, $P$. hydropathica, and $P$. nicotianae were recovered from a small number of plants, but with no relationship to the original isolate inoculation treatments. All of the later three Phytophthora species were recovered from organic growing media, so mostly not associated with plant necrosis. P. cinnamomi was recovered from a few symptomatic roots of hydrangea in both trials and from Pieris in trial two. $P$. nicotianae was recovered from a few symptomatic roots of hydrangea in both trials and from rhododendron and one wounded collar of Pieris in trial one. P. hydropathica was recovered from one wounded collar of hydrangea in trial two. Most wounded collars of holly, hydrangea, pieris, rhododendron, and vinca healed without evidence of necrosis, while a local necrosis developed on 8 to $42 \%$ of each plant selection, with the exception of gardenia with no evidence of necrosis.

\section{Discussion}

Phytophthora spp. were recovered from all of the containment basins receiving runoff water from the nursery or water from a stream. Majority of these species found from the nursery ponds are known to inhabit aquatic environments, exemplified by $P$. gonapodyides, $P$. hydropathica, $P$. irrigata, and $P$. taxon PgChlamydo; and they are likely saprophytes of plant debris and opportunistic pathogens on ornamental plants (Kroon et al. 2012; Parke et al. 2014). A seasonal recovery pattern was observed with each species, but sampling and water quality measurements were not collected on sufficient number of days for comparative analysis.

Three Phytophthora species were found at the AL nursery in ponds A1 and A2. Both ponds are feed by a small stream and receive rainfall runoff from a wooded area on one side and irrigation runoff from the nursery on the other side, all being possible sources of
Phytophthora spp. Phytophthora spp. recovered from ponds A1 and A2 were similar, which was not unexpected, since water flows from pond A1 directly into A2 (Fig. 1). Of the two species recovered at higher frequency, $P$. gonapodyides was more prevalent in December and March and $P$. hydropathica more prevalent in May (Table 2). The month and temperature associations generally match the reported mycelium growth responses, in that optimum and maximum growth rates occur at higher temperatures for $P$. hydropathica than for $P$. gonapodyides (Hong et al. 2010). While the association between the highest temperature of recovery with an optimum in vitro growth response is expected, it does not validate a cause and effect relationship. Less in character was the recovery of hightemperature tolerant species $P$. irrigata in December (Hong et al. 2008a), which is in contrast to its optimum in vitro growth response. Recovery of $P$. irrigata in December presents the possibility of Phytophthora species being sporadically active even during less favorable temperature conditions, which could mean through much of the year in the Gulf Coast region. Also, it is possible that $P$. irrigata exists in ponds A1 and A2, but at a much lower population level than $P$. hydropathica. This could result in $P$. irrigata being undetected during warmer months, but recoverable when the $P$. hydropathica

Table 2. Diversity and population totals of Phytophthora species recovered via baiting with Rhododendron leaves from three possible depths (nearsurface, middle, and near-bottom) of three nursery ponds $\mathrm{A} 1, \mathrm{~A} 2$, and $\mathrm{A} 3$ in Alabama

\begin{tabular}{lcrrr}
\hline & & \multicolumn{3}{c}{$\begin{array}{c}\text { Total colony counts } \\
\text { per pond }\end{array}$} \\
\cline { 3 - 5 } Month, year & Phytophthora species & $\mathbf{A 1}$ & $\mathbf{A 2}$ & $\mathbf{A 3}$ \\
\hline May 2011 & P. gonapodyides & 0 &. & 0 \\
March 2012 & P. hydropathica & 55 &. & 0 \\
& P. gonapodyides & 20 & 22 & 0 \\
December 2012 & P. hydropathica & 1 & 2 & 0 \\
& P. gonapodyides & 24 & 29 & 0 \\
& P. hydropathica & 8 & 7 & 0 \\
& P. irrigata & 1 & 0 & 0
\end{tabular}

a Total counts of each Phytophthora spp. recovered from leaf baits on $\mathrm{P}_{10} \mathrm{ARP}$ agar. Ponds A1, A2, and A3 were sampled at 3,2, and 2 depths, respectively.

${ }^{\mathrm{b}}$ Leaf baits were placed in pond A2 in May 2011, but were missing 7 days later along with the bobber floats, swivels, and weights. At later sampling dates, floats in A2 were placed just below the water surface, to be less visible.

Table 3. Diversity and population totals of Phytophthora species recovered via baiting with Rhododendron leaves from three depths (near-surface, middle, and near-bottom) of five nursery ponds M1, M2, M3, M4, and M5 in Mississippi

\begin{tabular}{llrrrrr}
\hline & & \multicolumn{5}{c}{ Total colony counts per pond } \\
\cline { 2 - 7 } Month, year & Phytophthora species & M1 & M2 & M3 & M4 & M5 \\
\hline May 2011 & P. gonapodyides & 0 & \multicolumn{1}{c}{ b } & 0 & 0 & 0 \\
February 2012 & P. hydropathica & 34 &. & 28 & 0 & 28 \\
& P. gonapodyides & 14 & 55 & 38 & 3 & 4 \\
& P. hydropathica & 4 & 2 & 1 & 0 & 1 \\
& P. macilentosa & 0 & 0 & 0 & 2 & 0 \\
& P. mississippiae & 0 & 0 & 0 & 4 & 0 \\
November 2012 & P. stricta & 0 & 0 & 0 & 4 & 0 \\
April 2013 & P. gonapodyides & 17 & 0 & 0 & 1 & 0 \\
& P. hydropathica & 6 & 16 & 4 & 0 & 7 \\
& P. gonapodyides & 0 & 0 & 0 & 0 & 0 \\
& P. hydropathica & 0 & 0 & 2 & 0 & 2 \\
& P. 'Pgchlamydo' & 0 & 18 & 4 & 0 & 15 \\
& P. macilentosa & 0 & 0 & 0 & 18 & 0 \\
& P. citrophthora & 0 & 1 & 0 & 0 & 2 \\
\hline
\end{tabular}

a Total colony counts of each Phytophthora spp. recovered from leaf baits on $\mathrm{P}_{10} \mathrm{ARP}$ agar.

b Pond M2 was not sampled in May 2011. 
population is low during cooler months (Brasier et al. 1993, 2003). Another possibility is that $P$. irrigata is a slow colonizer of rhododendron leaves, so that its presence may be overlooked during summertime and present only at a low frequency in winter samplings. It was interesting that $P$. nicotianae was not recovered in ponds A1 and A2, since $P$. nicotianae-infected plants were found close to A1 several months prior to the May 2011 pond sample collection. The plants had been discarded prior to May 2011.

No Phytophthora species was detected in any sampling period from pond A3 at the AL nursery (Table 2). Pond A3 is filled with well water and rain water and completely surrounded by a raised berm. Apparently, no Phytophthora spp. had been introduced into and become established as a residence of pond A3. This finding indicates that well and rain water were the cleanest sources of irrigation water at the AL nursery. It may also exclude the possibility of Phytophthora species being introduced in ponds $\mathrm{A} 1$ and $\mathrm{A} 2$ directly from rainfall.

Four Phytophthora species were recovered from three interconnected ponds, M1, M2, and M3, located in a centralized location within a MS nursery. The majority of runoff is channeled into M1, which collects much of the sedimentation, then dependent on water volume overflows in series into M2, a lagoon, and M3 (Fig. 2). Each of the three ponds and the lagoon can receive runoff directly during heavy rainfall events. $P$. gonapodyides and $P$. hydropathica were the only species recovered from M1 and were recovered at a high frequency in M2 and M3 also (Table 3). The prevalence of these two species in containment basins demonstrate they are well adapted to an aquatic environment. The high numbers of $P$. gonapodyides and $P$. hydropathica recovered from M1 indicate a possibility that both species also survive and propagate in the nursery habitat, either with container-grown plants and/or in localized wet soil habitats, and are regularly transported in runoff. $P$. gonapodyides was dominant in a cool month (February) and $P$. hydropathica in a warm month (May), similar to the seasonal recovery pattern found at the AL nursery (Table 3). $P$. taxon PgChlamydo and $P$. citrophthora were recovered at a lower frequency and only in April. Seasonal recovery supports a concept of an environmental influence that is at least in part affected by temperature (Bush et al. 2003).

Pond M4 had a different composition of four Phytophthora species than the previously mentioned MS ponds (Table 3). P. hydropathica was not recovered from M4 and $P$. gonapodyides was recovered in low numbers. Additionally, three novel species were recovered from M4, with each being assigned a species nomenclature (Yang et al. 2013, 2014). Of those, P. macilentosa was the most abundant species recovered. Pond M4 receives no runoff from the nursery, but is fed by a stream and receives rainfall runoff from the surrounding forest. Whether these three new species have become established in the pond is unknown. Possibly they were carried into pond M4 through flash flood runoff from nearby forests. Pond M4 is a primary water source for pumping irrigation water to a portion of the nursery where large container-grown plants are grown, therefore the three Phytophthora spp. are likely being introduced into the nursery. From these findings, M4 appears to have a different Phytophthora spp. composition than the ponds recharged primarily from irrigation runoff.

Pond M5 had a diversity that reflected those recovered from M2, which sometimes flows directly into M5 (Table 3). M4 is also a source of water pumped into M5. The new Phytophthora spp. detected in M4 were not detected in M5, which may be a result of sampling density. Differences in Phytophthora species composition between all ponds reflects the source of water, whether from irrigation runoff or successional pond flow patterns. Results fit the emerging pattern of aquatic and terrestrial habitat specialization for different members of the Phytophthora community.

In vivo assessment of pathogenicity of the three new species, $P$. macilentosa, $P$. mississippiae, and $P$. stricta initially recovered from pond M4 was performed at two different times of the year, spring to summer and summer to winter, in part to take advantage of seasonal temperature differences that might influence success of infection, colonization, and establishment in the organic rooting media. The three species did not infect the plants nor persist in the organic rooting media, indicating a low risk to cause episodic disease in the nursery. This phenomenon of aquatic Phytophthora spp. having low aggressiveness has been reported by others (Loyd et al. 2014; Tjosvold et al. 2008). Many aquatic Phytophthora species are associated with subclade $6 \mathrm{~b}$ and clade 9 of the genus Phytophthora. Species in these two phylogenetic groups are often recovered from irrigation water at plant nurseries (Loyd et al. 2014; Parke et al. 2014). Of the species tested in the current study, P. mississippiae is grouped in Phytophthora clade 6b, which was projected to be a potential saprophyte and cause minor plant disease. P. macilentosa is phylogenetically grouped in a high temperaturetolerant cluster in clade 9, which includes many species that lack pathogenicity records. Although attention should be paid to these high temperature-tolerant species for potential of emerging pathogenicity when temperature increases, most of these species are currently believed to pose limited plant health risk. $P$. stricta is phylogenetically grouped in a previously unknown ITS clade of the genus Phytophthora (Yang et al. 2014). Additionally, its pathogenic role is unknown.

$P$. cinnamomi, $P$. drechsleri, and $P$. nicotianae were found causing root and collar diseases and inhabiting the organic growing media. These three species are most likely from the wholesale nurseries where the test plants were purchased, since the irrigation water at the TCSHL test site originates from a well and the slope of the irrigation pad directs runoff away from plants. It was noted that $P$. cinnamomi, $P$. drechsleri, P. nicotianae, and other prominent Phytophthora pathogens were not detected from any of the irrigation reservoirs surveyed in the present study.

These findings accord with previous observations that the composition of terrestrial and aquatic Phytophthora communities may be different (Hansen et al. 2012; Parke et al. 2014). Lack of detection of major pathogenic Phytophthora species from these reservoirs could be due in part to their low concentration in the systems as a result of strict sanitation and other best management practices followed in both nurseries or due to insufficient sampling intensity. Neither the AL or MS nursery have had severe disease outbreaks associated with any of the Phytophthora spp. recovered from the containment basins that serve as a primary source of irrigation water. Additionally, two of the six plant varieties used to test virulence of $P$. macilentosa, $P$. mississippiae, and $P$. stricta are produced in 57- and 114-liter containers at the MS nursery and irrigated with water from M4, where these isolates were recovered. None of the three newly named Phytophthora spp. have been found causing disease in the nursery.

While a relatively small Phytophthora community of nine species was recovered in this study, the actual Phytophthora diversity in the surveyed containment basins is likely greater than recovered. Many Phytophthora spp. existing in the irrigation water at low abundance levels may not be detected using conventional detection methods such as the baiting method used in this study. This is especially possible when the Phytophthora community is dominated by one or a couple of species such as $P$. gonapodyides in winter and $P$. hydropathica in summer as shown in this study. Thus, a comprehensive recovery of Phytophthora spp. requires larger and more frequent sampling (Zappia et al. 2014) or use of modern molecular detection methods such as cloning (Scibetta et al. 2012) and next-generation sequencing.

All recovered Phytophthora spp. in this study have not been found causing any plant disease locally or considered as highly virulent pathogens in nurseries. Also, the three new species were not virulent on several important plant selections. However, it is not for certain that these species will not cause plant disease in the future. Many studies have shown that some species recovered in this study including $P$. citrophthora, $P$. hydropathica, $P$. pini, and $P$. taxon PgChlamydo can cause diseases on nursery crops (Blomquist et al. 2012; Hong et al. 2008b, 2010; Vitale et al. 2014). The exact economic importance of these Phytophthora spp. in irrigation systems of Mississippi and Alabama nurseries also requires larger, more frequent, and longer-term monitoring. 


\section{Acknowledgments}

The research was supported in part through the US Department of Agriculture, Agricultural Research Service, Thad Cochran Southern Horticultural Laboratory, Southern Horticultural Research Unit project number 6404-21430-001-00D and in part by grants from USDA/NIFA (2010-51181-21140). We thank Mrs. Patricia Richardson for her assistance in performing single-stranded complementary polymorphism (SSCP) of some isolates, verifying identification to species using morphological traits, submitting reports to the group, and generating PCR products and submitting them for DNA sequencing. We also thank both nurseries for allowing our survey of their reservoirs and providing on-site assistances.

\section{Literature Cited}

Blomquist, C. L., Yakabe, L. E., Soriano, M. C., and Negrete, M. A. 2012. First report of leaf spot caused by Phytophthora taxon Pgchlamydo on evergreen nursery stock in California. Plant Dis. 96:1691.

Brasier, C. M., Cooke, D. E. L., Duncan, J. M., and Hansen, E. M. 2003. Multiple new phenotypic taxa from trees and riparian ecosystems in Phytophthora gonapodyides- $P$. megasperma ITS Clade 6 , which tend to be hightemperature tolerant and either inbreeding or sterile. Mycol. Res. 107:277-290.

Brasier, C. M., Hamm, P. B., and Hansen, E. M. 1993. Cultural characters, protein patterns and unusual mating behaviour of Phytophthora gonapodyides isolates from Britain and North America. Mycol. Res. 97:1287-1298.

Bush, E. A., Hong, C. X., and Stromberg, E. L. 2003. Fluctuations of Phytophthora and Pythium spp. in components of a recycling irrigation system. Plant Dis. 87: 1500-1506.

Cobb, R. C., Chan, M. N., Meentemeyer, R. K., and Rizzo, D. M. 2012. Common factors drive disease and coarse woody debris dynamics in forests impacted by sudden oak death. Ecosystems (N. Y.) 15:242-255.

Dart, N. L., and Chastagner, G. A. 2007. High recovery rate of Phytophthora from containerized nursery stock pots at a retail nursery highlights potential for spreading exotic oomycetes. Plant Health Prog. Online publication, doi: http://dx. doi.org/10.1094/PHP-2007-0816-01-BR

Dart, N. L., Chastagner, G. A., Rugarber, E. F., and Riley, K. L. 2007. Recovery frequency of Phytophthora ramorum and other Phytophthora spp. in the soil profile of ornamental retail nurseries. Plant Dis. 91:1419-1422.

Erwin, D. C., and Ribeiro, O. K. 1996. Phytophthora diseases worldwide. APS Press, St. Paul, MN

Gallegly, M. E., and Hong, C. 2008. Phytophthora: identifying species by morphology and DNA fingerprints. APS Press, St. Paul, Minnesota.

Ghimire, S. R., Richardson, P. A., Hong, C. X., Moorman, G. W., Lea-Cox, J. D., and Ross, D. S. 2009. An in-situ baiting bioassay for detecting Phytophthora species in irrigation runoff containment basins. Plant Pathol. 58:577-583.

Ghimire, S. R., Richardson, P. A., Kong, P., Hu, J., Lea-Cox, J. D., Ross, D. S., Moorman, G. W., and Hong, C. 2011. Distribution and diversity of Phytophthora species in nursery irrigation reservoir adopting water recycling system during winter months. J. Phytopathol. 159:713-719.

Hansen, E. M., Reeser, P. W., and Sutton, W. 2012. Phytophthora beyond agriculture. Annu. Rev. Phytopathol. 50:359-378.

Hong, C. X., Gallegly, M. E., Richardson, P. A., Kong, P., and Moorman, G. W. 2008a. Phytophthora irrigata, a new species isolated from irrigation reservoirs and rivers in Eastern United States of America. FEMS Microbiol. Lett. 285: 203-211.

Hong, C. X., Gallegly, M. E., Richardson, P. A., Kong, P., Moorman, G. W., LeaCox, J. D., and Ross, D. S. 2010. Phytophthora hydropathica, a new pathogen identified from irrigation water, Rhododendron catawbiense and Kalmia latifolia. Plant Pathol. 59:913-921.

Hong, C. X., and Moorman, G. W. 2005. Plant pathogens in irrigation water: Challenges and opportunities. Crit. Rev. Plant Sci. 24:189-208.

Hong, C. X., Richardson, P. A., Hao, W., Ghimire, S. R., Kong, P., Moorman, G. W., Lea-Cox, J. D., and Ross, D. S. 2012. Phytophthora aquimorbida sp. nov. and Phytophthora taxon 'aquatilis' recovered from irrigation reservoirs and a stream in Virginia, USA. Mycologia 104:1097-1108.

Hong, C., Richardson, P. A., and Kong, P. 2008b. Pathogenicity to ornamental plants of some existing species and new taxa of Phytophthora from irrigation water. Plant Dis. 92:1201-1207.
Jeffers, S. N., and Martin, S. B. 1986. Comparison of two media selective for Phytophthora and Pythium species. Plant Dis. 70:1038-1043.

Jung, T., Hardy, G. E. S. J., White, D., Paap, T., Dunstan, W. A., Burgess, T. I., and Stukely, M. J. C. 2011. Multiple new Phytophthora species from ITS clade 6 associated with natural ecosystems in Australia: Evolutionary and ecological implications. Persoonia 26:13-39.

Kong, P., Hong, C. X., Richardson, P. A., and Gallegly, M. E. 2003. Single-strandconformation polymorphism of ribosomal DNA for rapid species differentiation in genus Phytophthora. Fungal Genet. Biol. 39:238-249.

Kroon, L. P. N. M., Brouwer, H., de Cock, A. W. A. M., and Govers, F. 2012. The genus Phytophthora anno 2012. Phytopathology 102:348-364.

Loyd, A. L., Benson, D. M., and Ivors, K. L. 2014. Phytophthora populations in nursery irrigation water in relationship to pathogenicity and infection frequency of Rhododendron and Pieris. Plant Dis. 98:1213-1220.

Olson, H. A., and Benson, D. M. 2011. Characterization of Phytophthora spp. on floriculture crops in North Carolina. Plant Dis. 95:1013-1020.

Olson, H. A., Jeffers, S. N., Ivors, K. L., Steddom, K. C., Williams-Woodward, J. L., Mmbaga, M. T., Benson, D. M., and Hong, C. X. 2013. Diversity and mefenoxam sensitivity of Phytophthora spp. associated with the ornamental horticulture industry in the Southeastern United States. Plant Dis. 97:86-92.

Parke, J. L., Knaus, B. J., Fieland, V. J., Lewis, C., and Grünwald, N. J. 2014 Phytophthora community structure analyses in Oregon nurseries inform systems approaches to disease management. Phytopathology 104:1052-1062.

Rizzo, D. M., Garbelotto, M., Davidson, J. M., Slaughter, G. W., and Koike, S. T. 2002. Phytophthora ramorum as the cause of extensive mortality of Quercus spp. and Lithocarpus densiflorus in California. Plant Dis. 86:205-214.

Rizzo, D. M., Garbelotto, M., and Hansen, E. A. 2005. Phytophthora ramorum: Integrative research and management of an emerging pathogen in California and Oregon forests. Annu. Rev. Phytopathol. 43:309-335.

Schwingle, B. W., and Blanchette, R. A. 2008. Host range investigations of new, undescribed, and common Phytophthora spp. isolated from ornamental nurseries in Minnesota. Plant Dis. 92:642-647.

Schwingle, B. W., Smith, J. A., and Blanchette, R. A. 2007. Phytophthora species associated with diseased woody ornamentals in Minnesota nurseries. Plant Dis. 91:97-102.

Scibetta, S., Schena, L., Chimento, A., Cacciola, S. O., and Cooke, D. E. L. 2012 A molecular method to assess Phytophthora diversity in environmental samples. J. Microbiol. Methods 88:356-368.

Stewart, S., and Robertson, A. E. 2012. A modified method to screen for partial resistance to Phytophthora sojae in soybean. Crop Sci. 52:1181-1186.

Tjosvold, S. A., Chambers, D. L., Koike, S. T., and Mori, S. R. 2008. Disease on nursery stock as affected by environmental factors and seasonal inoculum levels of Phytophthora ramorum in stream water used for irrigation. Plant Dis. 92: 1566-1573.

Vitale, S., Luongo, L., Galli, M., and Belisario, A. 2014. First report of Phytophthora hydropathica causing wilting and shoot dieback on viburnum in Italy. Plant Dis. 98:1582.

Warfield, C. Y., Hwang, J., and Benson, D. M. 2008. Phytophthora blight and dieback in North Carolina nurseries during a 2003 survey. Plant Dis. 92: 474-481.

Yakabe, L. E., Blomquist, C. L., Thomas, S. L., and MacDonald, J. D. 2009 Identification and frequency of Phytophthora species associated with foliar diseases in California ornamental nurseries. Plant Dis. 93:883-890.

Yang, X., Copes, W. E., and Hong, C. X. 2013. Phytophthora mississippiae sp. nov., a new species recovered from irrigation reservoirs at a plant nursery in Mississippi. J. Plant Pathol. Microbiol. 4:180.

Yang, X., Copes, W. E., and Hong, C. X. 2014. Two novel species representing a new clade and cluster of Phytophthora. Fungal Biol. 118:72-82.

Yang, X., and Hong, C. X. 2013. Phytophthora virginiana sp. nov., a high-temperature tolerant species from irrigation water in Virginia. Mycotaxon 126:167-176.

Yang, X., Richardson, P. A., Ghimire, S. R., Kong, P., and Hong, C. X. 2012 Phytophthora hedraiandra detected from irrigation water at a perennial ornamental plant nursery in Virginia. Plant Dis. 96:915.

Zappia, R. E., Hüberli, D., Hardy, G. E. S., and Bayliss, K. L. 2014. Fungi and oomycetes in open irrigation systems: knowledge gaps and biosecurity implications. Plant Pathol. 63:961-972. 